\title{
Gambaran Keluhan Low Back Pain (LBP) pada Pekerja Menjahit dengan Pengukuran Visual Analog Scale (VAS)
}

\author{
Lita Aprilia $^{1 *}$, Solichin², Sendhi Tristanti Puspitasari ${ }^{3}$ \\ 1,3Jurusan IImu Kesehatan Masyarakat, Fakultas IImu Keolahragaan, Universitas Negeri Malang, \\ Jalan Semarang No 5, Malang, Jawa Timur, 65145, Indonesia \\ 2Jurusan Teknik Mesin, Fakultas Teknik, Universitas Negeri Malang, Jalan Semarang No 5, Malang, \\ Jawa Timur, 65145, Indonesia \\ *Penulis koresponden: litaap84@gmail.com, 085894774180
}

Artikel diterima: 7 Januari 2021; direvisi: 15 Maret 2021; disetujui: 20 Maret 2021

\begin{abstract}
Low back pain (LBP) is a symptom or pain syndrome that occurs in the lower back which is the result of various factors and is one of the contributors to disability and occupational diseases. The research objective is to find out the presence of LBP complaints in sewing workers at PT Dwi Putra Perkasa Malang City using a visual analog scale (VAS) assessment. The study was conducted using a cross sectional method, with a sample size of 45 workers. The results obtained are the average and the most in the class ification of mild pain at 2 hours of work as many as 26 respondents (57.8\%) and at 4 hours of work as many as 31 respondents $(66.7 \%)$. Conclusion: Complaints from LBP sewing workers at PT Dwi Putra Perkasa Malang using the visual analog scale (VAS) assessment obtained the average classification and the most were mild pain, both at 2 hours of work and at 4 hours of work.
\end{abstract}

Keyword: low back pain (LBP), visual analog scale (VAS), sewing workers

\begin{abstract}
Abstrak: Low back pain (LBP) adalah suatu gejala atau sindroma nyeri yang terjadi pada punggung bawah yang merupakan akibat dari berbagai faktor dan merupakan salah satu penyumbang terjadinya kecacatan serta penyakit akibat kerja. Tujuan penelitian yaitu untuk dapat mengetahui terdapatnya keluhan LBP pada pekerja bagianmenjahit di PT Dwi Putra Perkasa Kota Malang menggunakan penilaian visual analog scale (VAS). Penelitian dilakukan menggunakan metode cross sectional, dengan jum lah sampel 45 pekerja. Hasil yang diperoleh yaitu rata -rata dan paling banyak pada klasifikas i nyeri ringan pada 2 jam kerja sebanyak 26 responden $(57,8 \%)$ dan pada 4 jam kerja sebanyak 31 responden (66,7\%). Kesimpulan: Keluhan LBP pekerja bagian menjahit di PT Dwi Putra Perkasa Malang dengan menggunakan penilaian visual analog scale (VAS) diperol eh klasifikasi rata-rata dan paling banyak pada nyeri ringan, baik pada 2 jam kerja dan pada 4 jam kerja.
\end{abstract}

Kata kunci: low back pain (LBP), visual analog scale (VAS), pekerja menjahit 


\section{PENDAHULUAN}

LBP merupakan permasalahan kesehatan yang sangat umum pada populasi dan penyebab utama kecatatan yang memengaruhi kinerja dan kesejahteraan. Prevalensi seumur hidup dari LBP secara umum (non-specific) diperkirakan $60-70 \%$ di negara-negara industri (prevalensisatu tahun $15-45 \%$, kejadian pada orang dewasa $5 \%$ pertahun). LBP meningkat di antara usia 35 sapaim 55 tahun. Seiring bertambahnya usia populasi di dunia, LBP akan meningkat secara substansial disebabkan kerusakan tulang cakram (Beatrice Duthey, 2013).

Hal tersebut National Institutes of Heath $(\mathrm{NIH})$ menyampaikan bahwa sekitar $80 \%$ orang dewasa mengalami LBP pada suatu waktu dalam hidup mereka. Hal tersebut merupakan penyebab paling umum dari kecacatan berhubungan dengan pekerjaan dan penyebab utama hilangnya hari kerja. Sebuah survei besar menyatakan, lebih dari seperempat orang dewasa dilaporkan mengalami nyeri punggung bawah selama 3 bulan terakhir pada tahun 2014.

LBP merupakan nyeri neuropatik yang sangat sering ditemukan di Indonesia, dan berdasarkan informasi dari Kementerian Kesehatan disampaikan bahwa prevalensi LBP di Indonesia sebesar $18 \%$. Prevalensi LBP meningkat sesuai dengan bertambahnya usia dan paling sering terjadi pada usia dekade tengah dan awal dekade empat. Penyebab LBP sebagian besar (85\%) adalah nonspesifik, akibat kelainan pada jaringan lunak, berupa cedera otot, ligamen, spasme atau keletihan otot. Penyebab lain yang serius adalah spesifik antara lain, fraktur vertebra, infeksi dan tumor.

Tinjauan sistematis Meucci, Fassa and Faria (2015) pada dua penelitian dari Freburger JK., dkk (2009) dan Hagen K., dkk (2011) menunjukkan bahwa prevalensi LBP berlipat ganda seiring waktu. Ini mungkin mencerminkan perubahan penting dalam gaya hidup dan di dunia kerja. Penggunaan intensif komputer di tempat kerja dan di rumah serta teknologi lainnya telah meningkatkan ketajaman faktor risiko untuk LBP kronis dan akut karena kelemahan otot.

Penelitian Hayati, Kusuma and Hasan (2014) yang berjudul Pengaruh Posisi Kerja terhadap Kejadian Low Back Pain pada Pekerja di Kampung Sepatu Kelurahan Miji-Prajurit Kulon-Mojokerto dijelaskan bahwa posisi kerja memiliki pengaruh terhadap terjadinya LBP pada pekerja di Kampung Sepatu. Hal ini disebabkan karena posisi kerja yang salah dan tidak ergonomi. Posisi kerja berdiri maupun duduk keduanya mempunyai pengaruh yang signifikan terhadap kejadian LBP. Namun jika dibandingkan secara lebih rinci, maka posisi kerja duduk lebih tinggi pengaruhnya dibanding dengan posisi kerja berdiri (Hayati, et al., 2014).

PT Dwi Putra Perkasa adalah salah satu industri garmen yang berada di Kota Malang Jawa Timur. Berdasarkan hasil observasi pendahuluan oleh peneliti pada tanggal 3 November 2018 sampai tanggal 10 November 2018 di tempat produksi utama ditemukan bahwa pekerja lebih banyak melakukan pekerjaannya dengan posisi duduk, khusunya pada bagian menjahit dan yang menggunakan alat jahit dengan jam kerja 8 jam per hari selama enam hari kerja. Pengukuran Nordic Body Map (NBM) pada pekerja bagian menjahit menunjukkan bahwa 68,63\% mengalami keluhan sakit pada daerah punggung, 27,45\% mengalami keluhan sakit pada daerah bahu kanan, $25,49 \%$ mengalami keluhan sakit pada daerah leher, $23,53 \%$ mengalami keluhan sakit pada daerah bahu kiri, dan 21,57\% mengalami keluhan sakit pada daerah siku kanan.

Keluhan pada beberapa daerah muskuloskeletal berdasarkan pengamatan dapat dikarenakan pekerja bekerja dalam keadaan statis selama 8 jam kerja dengan posisi kerja duduk yang kurang nyaman dan kurang ergonomis. Dapat dikarenakan juga oleh station kerja atau kursi kerja yang tidak disesuaikan dengan antropometri pekerja, sehingga pekerja banyak yang mengeluhkan ketidaknyamanan dan rasa nyeri atau sakit pada otot rangka, terutama yang paling tinggi persentasenya pada bagian punggung. Hal tersebut dapat meningkatkan resiko keluhan nyeri punggung bawah atau low back pain (LBP).

Berdasarkan penjelasan mengenai terjadinya LBP pada pekerja tersebut, peneliti melakukan penelitian yang dapat menjelaskan gambaran terjadinya LBP pada pekerja bagian menjahit di PT Dwi Putra Perkasa Kota Malang. Tujuan penelitian yaitu untuk dapat mengetahui apakah terdapat keluhan nyeri Low Back Pain (LBP) pada pekerja bagian menjahit di PT Dwi Putra Perkasa Kota Malang dengan menggunakan penilaian visual analog scale (VAS). 


\section{METODE}

Penelitian ini merupakan penelitian deskriptif observasional yang berdasarkan pada kejadian atau peristiwa secara alami tanpa suatu perlakuan khusus terhadap kelompok yang diteliti. Metode yang digunakan yaitu metode cross sectional studies atau penelitian prevalensi. Populasi dalam penelitian ini adalah pekerja bagian menjahit di PT Dwi Putra Perkasa Kota Malang 2018 yang berjumlah 51 orang yang terdiri dari laki-laki dan perempuan. Pengambilan ukuran sampel dalam penelitian ini dengan teknik yang dikembangkan oleh Isaac dan Michael dengan taraf kesalahan 5\% adalah diperoleh jumlah sampel sebanyak 45 pekerja bagian menjahit yang bekerja dengan menggunakan alat atau mesin jahit listrik.

Teknik sampling yang digunakan pada penelitian ini yaitu teknik sampling random sederhana. Instrumen yang digunakan dalam penelitian ini adalah VAS (Visual Analog Scale). VAS digunakan untuk mengetahui nilai atau skala nyeri pada LBP. VAS berupa garis horizontal dengan panjang $100 \mathrm{~mm}$ dengan deskriptor verbal (jangkar kata) pada setiap ujung untuk mengungkapkan ekstrem dari perasaan, dan nilai VAS ditentukan dengan mengukur dalam milimeter dari ujung kiri garis ke titik yang ditandai oleh responden (Klimek et al., 2017).

Pengumpulan data dalam penelitian yaitu menggunakan VAS yang dilakukan dengan cara responden meberikan tanda di lembar pengukuran VAS tepat setelah dua jam kerja dan empat jam kerja. Penentuan waktu peniaian VAS tersebut sesuai dengan waktu yang dianjurkan bagi pekerja untuk melakukan peregangan pada tubuh, yaitu setiap dua jam kerja seperti yang diterapkan pada penelitian Darma (2018) pada penelitiannya tentang pemberian dynamic stretching dan pemberian istirahat pendek untuk mengurangi work related MSDs pegawai pemerintahan. Waktu peregangan tubuh pada penelitian tersebut didasarkan dari ILO yang menganjurkan istirahat kerja selama 10-15 menit pada pekerja yang bekerja lebih dari 4 jam.

\section{HASIL}

Karakteristik responden yang diteliti pada penelitian ini yaitu terdiri dari jenis kelamin, usia, dan masa kerja. distribusi karakteristik responden penelitian ini yaitu sebagai berikut.

Tabel 1. Distribusi frekuensi karakteristik responden pekerja bagian menjahit di PT Dwi Putra Perkasa Kota Malang 2019.

\begin{tabular}{|c|c|c|}
\hline Karakteristik Responden & Frekuensi (n) & Persentase (\%) \\
\hline \multicolumn{3}{|l|}{ Jenis Kelamin } \\
\hline Laki-laki & 8 & 17.8 \\
\hline Perempuan & 37 & 82.2 \\
\hline \multicolumn{3}{|l|}{ Usia } \\
\hline$<25$ tahun & 20 & 44.44 \\
\hline 25-35 tahun & 9 & 20.00 \\
\hline$>35$ tahun & 16 & 35.56 \\
\hline \multicolumn{3}{|l|}{ Masa Kerja } \\
\hline$<6$ tahun & 35 & 77.78 \\
\hline $6-10$ tahun & 9 & 20.00 \\
\hline$>10$ tahun & 1 & 2.22 \\
\hline
\end{tabular}

Berdarakan jenis kelamin pada tabel diperoleh hasil bahwa pekerja bagian menjahit di PT Dwi Putra Perkasa rata-rata dan paling banyak adalah berjenis kelamin perempuan dengan jumlah 37 pekerja dari 45 pekerja, atau dengan persentase $82,2 \%$. Kelompok usia tertinggi berada pada kelompok usai $<25$ tahun yang berjumlah 20 responden (44,4\%), dan kelompok umur terendah berada pada kelompok usia 25-35 tahun yang berjumlah 9 responden $(20 \%)$. Rata-rata usia responden adalah 30 tahun, minimun usia responden adalah 16 tahun dan maksimum usia responden adalah 70 tahun, serta responden paling banyak berusia 16 tahun (5 responden) dan 17 tahun (5 responden). Masa kerja responden paling tinggi adalah $<6$ tahun masa kerja sebanyak 35 responden atau sebesar $(77,78 \%)$, sedangkan terendah adalah $>10$ tahun masa kerja sebanyak 1 responden $(2,22 \%)$, dengan rata-rata masa kerja responden adalah 3 tahun, minimum masa kerja responden adalah 0,17 tahun atau 2 bulan dan maksimum masa kerja adalah 17 tahun, serta responden paling banyak mempunyai masa kerja 2 tahun yaitu sebanyak 7 responden. 
Hasil penilaian VAS pada penelitian ini meliputi penilaian setiap 2 jam, yaitu pada 2 jam kerja dan 4 jam kerja pekerja bagian menjahit di PT Dwi Putra Perkasa. Penilaian tersebut diperoleh hasil sebagai berikut:

Tabel 2. Hasil penilaian Visual Analog Scale (VAS) 2 dan 4 jam kerja di PT Dwi Putra Perkasa Malang tahun 2019.

\begin{tabular}{ccc}
\hline Klasifikasi nyeri VAS (2 jam kerja) & Frekuensi & $\%$ \\
\hline 0-4 mm (tanpa rasa sakit) & 5 & 11.1 \\
\hline $5-44 \mathrm{~mm}$ (nyeri ringan) & 26 & 57.8 \\
\hline $45-74 \mathrm{~mm}$ (nyeri sedang) & 10 & 22.2 \\
\hline 75-100 mm (sakit parah) & 4 & 8.9 \\
\hline Total & 45 & 100.0 \\
\hline Klasifikasi nyeri VAS (4 jam kerja) & & \\
\hline $0-4 \mathrm{~mm}$ (tanpa rasa sakit) & 7 & 15.6 \\
\hline $5-44 \mathrm{~mm}$ (nyeri ringan) & 31 & 68.9 \\
\hline $45-74 \mathrm{~mm}$ (nyeri sedang) & 3 & 6.7 \\
\hline $75-100 \mathrm{~mm}$ (sakit parah) & 4 & 8.9 \\
\hline Total & 45 & 100.0 \\
\hline
\end{tabular}

Pekerja bagian menjahit di PT Dwi Putra Perkasa pada 2 jam kerja yang mengalami keluhan LBP dengan penilaian VAS paling banyak adalah pada klasifikasi nyeri ringan sebanyak 26 responden $(57,8 \%)$, dan paling sedikit adalah pada klasifikasi sakit parah sebanyak 4 responden $(8,9 \%)$. Sedangkan pada 4 jam kerja yang mengalami keluhan LBP dengan penilaian VAS paling banyak adalah pada klasifikasi nyeri ringan sebanyak 31 responden $(66,7 \%)$, dan paling sedikit adalah klasifikasi nyeri sedang sebanyak 3 responden $(6,7 \%)$. Pengukuran 2 jam kerja dan 4 jam kerja, keduanya menunjukkan bahwa rata-rata dan paling banyak dari pekerja bagian menjahit mengalami keluhan LBP pada klasifikasi nyeri ringan.

\section{PEMBAHASAN}

\section{Klasifikasi Responden}

Berdasarkan hasil penelitian yang telah dilakukan pada 45 responden atau pekerja bagian menjahit di PT Dwi Putra Perkasa Malang diperoleh hasil bahwa pekerja bagian menjahit lebih banyak berjenis kelamin perempuan dari pada berjenis kelamin laki-laki. Pekerja bagian menjahit berjenis kelamin perempuan sebanyak 37 pekerja dengan persentase $82,2 \%$ dan berjenis kelamin laki-laki sebanyak 8 pekerja dengan persentase $17,8 \%$. Hal tersebut mengartikan bahwa pekerja bagian menjahit di PT Dwi Putra Perkasa Malang paling banyak dan rata-rata berjenis kelamin perempuan.

Berdasarkan karakteristik usia diperoleh hasil bahwa usia pekerja bagian menjahit lebih banyak berusia $<25$ tahun yaitu sebanyak 20 pekerja dengan persentase 44,44\%. Sedangkan, kelompok usia 25-35 tahun sebanyak 9 pekerja dengan persentase $20 \%$ dan kelompok usia $>35$ tahun sebanyak 16 pekerja dengan persentase $35,56 \%$. Rata-rata usia pekerja bagian menjahit adalah 20 tahun, dengan minimum usia pekerja 16 tahun, maksimum usia pekerja 70 tahun, serta dari 45 pekerja paling banyak berusia 16 tahun.

Berdasarkan karakteristik masa kerja pekerja diperoleh hasil bahwa Pekerja bagian menjahit lebih banyak mempunyai masa kerja $<6$ tahun sebanyak 35 pekerja dengan persentase $77,78 \%$. Rata-rata masa kerja pekerja bagian menjahit yaitu 3 tahun. Masa kerja paling banyak mempunyai masa kerja 2 tahun yaitu sebanyak 7 responden.

\section{Low Back Pain}

Analisis tingkat keluhan LBP pada pekerja bagian menjahit di PT Dwi Putra Perkasa Malang dengan menggunakan metode pengukuran VAS yang dilakukan pengukuran pada 2 jam kerja dan pada 4 jam kerja. Hasil yang diperoleh yaitu, nilai pengukuran VAS pada 2 jam kerja rata-rata $32,16 \mathrm{~mm}$ atau keluhan LBP pekerja bagian menjahit dalam klasifikasi nyeri ringan, serta keluhan LBP paling banyak pada klasifikasi nyeri ringan (nilai 5-44 mm) sebanyak 26 responden dengan persentase (57,8\%). Sedangkan untuk nilai pengukuran VAS pada 4 jam kerja diperoleh hasil rata-rata $27,87 \mathrm{~mm}$ atau keluhan LBP pekerja bagian 
menjahit dalam klasifikasi nyeri rungan dan paling banyak adalah pada klasifikasi nyeri ringan (nilai 5-44 mm) sebanyak 31 responden dengan persentase $(66,7 \%)$. Pengukuran 2 jam kerja dan 4 jam kerja, keduanya menunjukkan bahwa rata-rata dan paling banyak dari pekerja bagian menjahit di PT Dwi Putra Perkasa Malang mengalami keluhan LBP pada klasifikasi nyeri ringan.

Keluhan LBP pada dasarnya tidak hanya dipengaruhi oleh satu faktor risiko saja. Seperti yang disampaikan oleh Iridiastadi (2016:71) bahwa suatu gangguan pada sistem otot rangka dapat disebabkan oleh satu atau kombinasi beberapa faktor risiko. Semakin banyak faktor risiko yang melekat pada suatu pekerjaan, risiko yang mungkin terjadi juga semakin besar.

Penyebab timbulnya nyeri punggung yang disampaikan Beatrice Duthey (2013) sebagian kecil kasus LBP disebabkan oleh trauma pada punggung, osteoporosis, atau penggunaan kortikosteroid yang berkepanjangan, dan yang relatif lebih jarang adalah infeksi tulang belakang, tumor dan metastasis tulang. Disampaikan Saleh (2018: 227) penyebab onset nyeri punggung bawah tetap tidak jelas dan sulit dilakukan diagnosis, karena nyeri punggung bukanlah suatu penyakit melainkan konstelasi gejala. Menurut (Rehatta et al., 2019: 1143) nyeri punggung terasa dalam dan bertambah berat dengan aktivitas atau kegiatan bekerja, nyeri seperti terbakar atau tertusuk yang lebih mengarah pada nyeri neuropatik.

Berdasarkan gejala nyeri yang dirasakan oleh subjek penelitian, berat atau ringannya suatu keluhan nyeri bersifat subjektif, oleh karenanya pada pengkajian tersebut estimasi harus ditentukan oleh subjek sendiri. Rasa nyeri berbeda dari satu individu dan individu yang lain berdasarkan atas ambang nyeri dan toleransi nyeri pada masing-masing individu. Pengkajian maupun penanganannya harus dibedakan pula untuk setiap orang.

\section{Faktor Risiko}

Berdasarkan dari karakteristik responden, yang menjadi salah satu yang memungkinkan berpengaruh pada hasil penelitian adalah faktor karakteristik usia. Rata-rata tersebut merupakan usia yang masih kategori remaja akhir (17-25 tahun), sehinga mengartikan bahwa sifat fisiologi pada otot rangka pada responden masih dalam keadaan baik serta keluhan LBP jarang terjadi. Tarwaka (2015) menyatakan bahwa keluhan nyeri pertama biasanya dirasakan pada umur 35 tahun dan tingkat keluhannya akan semakin meningkat seiring dengan berjalannya waktu. Sedangkan pada hasil penelitian di studi cohort Thailand mengenai LBP dan keterbatasan dari kehidupan setiap hari di Asia yang dilakukan oleh Yiengprugsawan et al. (2017), disebutkan bahwa di Asia Tenggara, pada data nasional Thailand sekitar $80 \%$ pada rentang usia antara 30 dan 50 tahun menunjukkan preevalensi LBP.

Peningkatan frekuensi kejadian LBP seiring dengan peningkatan umur berhubungan dengan proses penuaan. Sejalan dengan meningkatnya usia akan terjadi degenerasi pada tulang. Pada usia 30 tahun terjadi degenerasi yang berupa kerusakan jaringan, penggantian jaringan menjadi parut, pengurangan cairan. Hal tersebut menyebabkan stabilitas pada tulang dan otot menjadi berkurang (Mario Polo Widjaya, Haeril Aswar, 2014). Berdasarkan Alnaami et al. (2019) pada penelitiannya disampaikan bahwa terjadinya LBP pada petugas kesehatan secara signifikan lebih tinggi terjadi di antara petugas kesehatan dalam kelompok usia antara 30 sampai 40 tahun dengan lamanya kondisi kerja.

Responden pada penelitian ini tidak diberikan batasan rentang usia, sehingga sebanyak 45 responden dalam penelitian terdapat responden yang berusia paling rendah yaitu 16 tahun dan paling tinggi yaitu 70 tahun. Rata-rata responden berusia 20 tahun dan paling banyak berusia 16 tahun. Berdasarkan usia responden tersebut sebagian besar pekerja bagian penjahit berada pada usia yang aktif dimana kondisi otot rangka yang cenderung masih sehat dan tidak banyak mengalami keluhan nyeri atau sakit pada muskuloskeletal khususnya pada bagian punggung atau punggung bawah.

Terdapat penelitian yang mengaitkan atau menanggapi mengenai faktor karakteristik jenis kelamin terhadap keluhan LBP, yang disampaikan Tarwaka (2015) menyebutkan kemampuan persentase otot perempuan lebih rendah dibandingkan dengan kekuatan otot laki-laki. Berdasrkan Wáng et al. (2016), bahwa pada perempuan mempunyai prevalensi LBP yang lebih tinggi di semua kelompok usia berdasarkan total 98 studi dengan 772.927 subjek yang dianalisis dengan dibagi menjadi empat kelopok usia yaitu kelompok anak usia sekolah (6-19 tahun), kelompok muda dan paruh baya (20-50 tahun), kelompok usia campuran (data dari penelitian tidak membedakan kelompok usia), dan kelompok lanjut usia ( $\geq 50$ tahun). Studi tersebut diperoleh hasil bahwa perempuan mempunyai prevalensi LBP yang lebih tinggi di semua kelompok usia. 
LBP ditinjau dari kejadiannya dapat berisiko tinggi pada jenis kelamin perempuan, seperti pernyataan yang disampaikan Andini (2015), bahwa prevalensi terjadinya LBP lebih banyak pada perempuan dibandingkan dengan laki-laki. Penelitian Kreshnanda (2016) tentang prevalensi dan gambaran keluhan LBP pada perempuan pekerja suun di Pasar Badung disampaikan bahwa sebagian besar perempuan pekerja suun telah menikah dan mempunyai anak, diperkirakan $50 \%$ dari wanita hamil akan menderita LBP selama kehamilan atau selama periode postpartum. Semakin sering melahirkan dapat menyebabkan fraktur kompresi pada korpus vertebrata walaupun oleh karena trauma kecil saja. Disampaikan juga bahwa perempuan mempunyai keluhan LBP lebih sering terjadi saat mengalami siklus menstruasi. Nyeri saat menstruasi terasa seperti tajam dan kram di bagian bawah perut yang biasanya menyebar ke bagian belakang, yaitu pinggang sehingga menimbulkan LBP.

Penelitian ini memperoleh hasil bahwa rata-rata masa kerja pekerja bagian menjahit adalah 3 tahun dan paling banyak mempunyai masa kerja 2 tahun. Masa kerja juga berperan dalam faktor risiko terhadap keluhan LBP. Dani Syuhada et al., (2018) menyampaikan bahwa pekerja yang banyak mengalami keluhan LBP adalah yang mempunyai masa kerja >10 tahun, sehingga apabila seseorang melakukan pekerjaan dengan keadaan yang tidak ergonomis dalam waktu yang lama dapat mengalami gangguan pada otot rangka. Berdasarkan Raya, Yunus and Adi (2019) disampaikan bahwa terdapat hubungan antara masa kerja dengan prevalensi dan tingkatan LBP, semakin lama masa kerja pekerja kuli angkut pasir maka semakin tinggi prevalensi dan tingkatan LBP.

Low back pain (LBP) adalah suatu gejala atau sindroma nyeri yang terjadi pada punggung bagian bawah yang merupakan akibat dari berbagai faktor dan merupakan salah satu penyumbang terjadinya kecacatan serta penyakit akibat kerja seperti yang dijelaskan Sitepu, Sinaga and Lubis (2015) bahwa gangguan ini paling banyak ditemukan di tempat kerja, terutama pada mereka yang beraktivitas dengan posisi tubuh yang salah. Rinadi et al., (2015) menjelaskan bahwa pekerja pada industri batu bara mendapat keluhan LBP akibat posisi kerja yang buruk dalam mengangkat beban, serta para pekerja memiliki kebiasaan memposisikan tubuh yang salah ketika bekerja misalnya, ketika mengangkat beban ada gerakan membungkuk dan memutar punggung, kegiatan yang dilakukan berulang-ulang, dan dalam mengangkat beban tidak berada sedekat mungkin dengan tubuh. Azkiya, Solichin and Puspitasari (2020), pada peneitiannya mengenai pengaruh sikap manual material handling siswa terhadap keluhan MSDs, disampaikan bahwa variabel "beban tas" terbukti berhubungan dengan keluhan MSDs. Menurut Iridiastadi (2016:70) Posisi netral (duduk dan berdiri secara normal) merupakan kondisi yang paling alamiah untuk bekerja, dengan usaha otot dan tekanan pada sendi, tendon, dan ligamen yang paling minimum. Berdasarkan pernyataan tersebut, pekerja bagian menjahit di PT Dwi Putra perkasa banyak yang bekerja dengan posisi atau sikap kerja seperti membungkuk dan ada juga yang memutar, yang merupakan posur yang salah, yang dapat berisiko terjadinya gangguan otot rangka atau MSDs dan juga kelelahan serta LBP yang dapat mengganggu kegiatan bekerja.

Penelitian yang dilakukan oleh Putranto et al., (2014) mengenai hubungan postur tubuh menjahit dengan keluhan LBP pada penjahit di pasar sentral kota Makassar, diperoleh hasil bahwa terdapat hubungan antara postur tubuh dengan keluhan LBP. Keadaan tersebut dapat terjadi akibat sikap duduk, tidur dan berdiri yang salah. Sikap kerja mempunyai hubungan dengan keluhan nyeri punggung bawah. Selain itu postur tubuh saat menjahit banyak diantaranya merupakan postur janggal misalnya duduk tanpa sandaran punggung atau pinggang, posisi punggung membungkuk dan ke depan, serta posisi bahu yang terangkat. Semua posisi tersebut merupakan posisi janggal yang dapat memicu terjadinya MSDs, khususnya LBP.

Kim et al. (2018) menyatakan dalam penelitiannya mengenai "Relationship between simultaneous exposure to ergonomic risk factors and work-related lower back pain: a crosssectional study based on the fourth Korean working conditions survey" atau "Hubungan Antara Simultan Paparan Faktor Risiko Ergonomis dan LBP Terkait Pekerjaan: Studi Crosssectional Berdasarkan Survei Kondisi Kerja Keempat Korea", bahwa ada hubungan yang kuat antara paparan yang parah pada setiap faktor risiko ergonomis (postur kelelahan dan menyakitkan; mengangkat atau menggerakkan orang; menyeret, mendorong, atau memindahkan benda berat; postur berdiri; dan gerakan tangan atau lengan berulang) secara signifikan dengan LBP yang terkait dengan pekerjaan. Namun, ketika terpapar 2 faktor risiko ergonomis secara bersamaan, hubungan antara pajanan dan LBP terkait pekerjaan tidak lebih kuat daripada bila hanya terpapar 1 faktor risiko. Hal tersebut dapat berarti bahwa terdapat 1 faktor risiko khususnya pada faktor ergonomis yang lebih kuat menjadi suatu penyebab terjadinya LBP dibandingkan dengan beberapa faktor risiko yang yang lainnya. 
Penting untuk diketahui bahwa LBP sudah menunjukkan menjadi suatu permasalahan di dunia, dengan peningkatan lebih jauh prevalensi LBP pada perempuan dan setelah usia menopause (Wáng et al., 2016). Oleh karena beberapa faktor lain, seperti metode penelitian yang digunakan juga merupakan sal ah satu faktor. Metode penelitian ini merupakan metode cross sectional yang dalam melakukan penelitian pada keluhan LBP yang diamati dalam satu waktu, yang dapat berubah nilai keluhannya seiring waktu dalam melakukan pekerjaan.

\section{KESIMPULAN}

Keluhan LBP pekerja bagian menjahit di PT Dwi Putra Perkasa Malang dengan menggunakan penilaian visual analog scale (VAS) diperoleh klasifikasi rata-rata dan paling banyak pada nyeri ringan. Pengukuran pada 2 jam kerja sebanyak 26 responden dengan persentase $57,8 \%$ dan pada 4 jam kerja sebanyak 31 responden dengan persentase $66,7 \%$. Anjuran atau saran dari penulis baik kepada pekerja atau masyarakat yaitu untuk menjaga dan memelihara kondisi kesehatan otot rangka dapat dilakukan dengan selalu mengkonsumsi makanan dan minuman yang bergizi dan mendukung kesehatan otot rangka, melakukan olahraga secara teratur, serta menjaga posisi kerja atau sikap kerja yang ergonomis.

\section{Ucapan Terima Kasih}

Penulis mengucapkan terimakasih kepada pihak-pihak yang telah membantu penyelesaian artikel ini. Penulis mengucapkan terimakasih kepada Dr. Sapto Adi, M.Kes, selaku Dekan Fakultas IImu Keolahragaan Universitas Negeri Malang, drg. Rara Warih Gayatri, M.PH, selaku Ketua Jurusan Kesehatan Masyarakat Universitas Negeri Malang, Drs. Solichin, S.T., M.Kes. selaku Pembimbing pertama, dr. Sendhi Tristanti Puspitasari, M.Kes., selaku pembimbing kedua, PT Dwi Putra Perkasa Kota Malang sebagai tempat penelitian, serta orang tua dan keluarga yang telah memberikan dukungan moral, material, dan selalu mendo'akan kelancaran penelitian dan terselesainya artikel ini.

\section{DAFTAR PUSTAKA}

Alnaami, I., Awadalla, N. J., Alkhairy, M., Alburidy, S., Alqarni, A., Algarni, A., Alshehri, R., Amrah, B., Alasmari, M., \& Mahfouz, A. A. (2019). Prevalence and factors associated with low back pain among health care workers in southwestern Saudi Arabia. BMC Musculoskeletal Disorders, 20(1), 1-7. https://doi.org/10.1186/s12891-019-2431-5

Andini, F. (2015). Fauzia Andini| Risk Factors of Low Back Pain in. In Workers J MAJORITY / (Vol. 4).

Azkiya, M. R., Solichin, \& Puspitasari, S. T. (2020). Pengaruh Sikap Manual Material Handling Siswa Terhadap Keluhan Musculoskeletal Disorders. Sport Science and Health, 2(2), 130-136.

Beatrice Duthey. (2013). A numerical approach for the prediction of shear strength of stiff fissured clay samples based on direct shear tests and FLAC modelling. The Geotechnics of Hard Soils - Soft Rocks. Proceedings of the Second International Symopsium on Hard Soils-Soft Rocks, Naples, October 1998. (Two Volumes)., March, 3-29.

Dani Syuhada, A., Suwondo, A., Setyaningsih, Y., \& Magister Promosi Kesehatan, A. (2018). Faktor Risiko Low Back Pain pada Pekerja Pemetik Teh di Perkebunan Teh Ciater Kabupaten Subang. In Jurnal Promosi Kesehatan Indonesia (Vol. 13, Issue 1).

Darma, I. W. E. W. (2018). Pemberian Dynamic Stretching dan Pemberian Istirahat Pendek untuk Mengurangi Work Related MSDs Pegawai Pemerintahan. http://digilib.unisayogya.ac.id/4198/1/NASKAH PUBLIKASI I WAYAN EKA.pdf

Hayati, K. F., Kusuma, I. F., \& Hasan, M. (2014). Pengaruh Posisi Kerja terhadap Kejadian Low Back Pain pada Pekerja ....

Iridiastadi, H. \& Y. (2016). Epidemiologi Suatu Pengantar. PT Remaja Rosdakarya.

Kim, J. Y., Shin, J. S., Lim, M. S., Choi, H. G., Kim, S. K., Kang, H. T., Koh, S. B., \& Oh, S. S. (2018). 
Relationship between simultaneous exposure to ergonomic risk factors and work-related lower back pain: A cross-sectional study based on the fourth Korean working conditions survey. Annals of Occupational and Environmental Medicine, 30(1). https://doi.org/10.1186/s40557-018-0269-1

Klimek, L., Bergmann, K. C., Biedermann, T., Bousquet, J., Hellings, P., Jung, K., Merk, H., Olze, H., Schlenter, W., Stock, P., Ring, J., Wagenmann, M., Wehrmann, W., Mösges, R., \& Pfaar, O. (2017). Visual analogue scales (VAS) - Measuring instruments for the documentation of symptoms and therapy monitoring in case of allergic rhinitis in everyday health care. Allergo Journal, 26(1), 36-47. https://doi.org/10.1007/s40629-016-0006-7

Kreshnanda, I. (2016). Prevalensi Dan Gambaran Keluhan Low Back Pain (Lbp) Pada Wanita Tukang Suun Di Pasar Badung, Januari 2014. E-Jurnal Medika Udayana, 5(8).

Mario Polo Widjaya, Haeril Aswar, S. P. (2014). Faktor-faktor yang berhubungan dengan kejadian low back pain pada pekerja furniture. Faktor-Faktor Yang Berhubungan Dengan Kejadian Low Back Pain Pada Pekerja Furniture, 85-90. http://ojs.uho.ac.id/index.php/medula/article/view/196

Meucci, R., Fassa, A., \& Faria, N. (2015). Prevalence of Chronic Low Back Pain: Systematic Review. https://www.ncbi.nlm.nih.gov/pmc/articles/PMC4603263/

Putranto, H., Djajakusli, T., Wahyuni, R., \& Andi. (2014). Hubungan Postur Tubuh Menjahit Dengan Keluhan Low Back Pain (LBP) Pada Penjahit Di Pasar Sentral Kota Makassar Relation Sew Body Posture with Low Back Pain (LBP) Complaints of Tailors in Sentral Market, Makassar City. Bagian Kesehatan Dan Keselamatan Kerja FKM Universias Hasanuddin, 1-11.

Raya, R. I., Yunus, M., \& Adi, S. (2019). Hubungan Intensitas Aktivitas Fisik dan Masa Kerja dengan Prevalensi dan Tingkatan Low Back Pain pada Pekerja Kuli Angkut Pasir. Sport Science and Health, 1(2), 102109.

Rehatta, N. M., Hanindito, E., Tantri, A. R., Redjeki, I. S., Soenarto, R. F., Bisri, D. Y., Musba, A. M. T., \& Lestari, M. I. (2019). Anastesiologi dan terapi intensif. PT Gramedia Pustaka Utama.

Rinadi, E., Utomo, Wasisto, \& Nauli, F. A. (2015). Hubungan Posisi Kerja pada Pekerja Industri Batu Bata dengan Kejadian Low Back Pain. Jurnal Online Mahasiswa Program Studi Ilmu Keperawatan Universitas Riau, 2(2), 1085-1093. https://media.neliti.com/media/publications/184011-ID-hubunganposisi-kerja-pada-pekerja-indus.pdf

Saleh, L. M. (2018). Keselamatn dan Kesehatan Kerja Kelautan: Kajian Keselamatan dan Kesehatan Kerja Sektor Maritim. CV Budi Utama.

Sitepu, D. S., Sinaga, M. M., \& Lubis, H. . (2015). Faktor-Faktor yang Berhubungan dengan Keluhan Low Back Pain pada Petani Jeruk di Desa Dokan Kecamatan Merek Kabupaten Karo Tahun 2015. Departemen Keselamatan Dan Kesehatan Kerja Fakultas Kesehatan Masyarakat Universitas Sumatera Utara.

Tarwaka. (2015). Ergonomi Industri Dasar-dasar Pengetahuan ergonomic dan Aplikasi di Tempat Kerja. Harapan Press.

Wáng, Y. X. J., Wáng, J. Q., \& Káplár, Z. (2016). Increased low back pain prevalence in females than in males after menopause age: Evidences based on synthetic literature review. Quantitative Imaging in Medicine and Surgery, 6(2), 199-206. https://doi.org/10.21037/qims.2016.04.06

Yiengprugsawan, V., Hoy, D., Buchbinder, R., Bain, C., Seubsman, S. A., \& Sleigh, A. C. (2017). Low back pain and limitations of daily living in Asia: Longitudinal findings in the Thai cohort study. BMC Musculoskeletal Disorders, 18(1). https://doi.org/10.1186/s12891-016-1380-5 